\title{
СОЦИОЛОГИЯ
}

И СОЦИАЛЬНЫЕ ТЕХНОЛОГИИ

\author{
DOI: https://doi.org/10.15688/lp.jvolsu.2018.1.7 \\ UDC 316.332 .6 \\ LBC 60.55
}

\section{THE DYNAMIC POTENTIAL OF SOCIETY}

\author{
Inna V. Vasilenko \\ Volgograd State University, Volgograd, Russian Federation
}

\begin{abstract}
The article attempts at constructing the methodological foundations of study of the social potential of the country, the region as a macro-social structure, the contradictions within which negatively affect the well-being of the population, its motivation and behavior. This article clarifies the concept of "dynamic potential of the society" as a set of changes occurring with all kinds of resources and opportunities of the society towards their increase or decrease. The dynamic Foundation of this potential is the human potential. Human potential is measured by the state of the population, including the working-age population, the level of employment and unemployment, labor productivity and motivation, the degree of differentiation of wages, the proportion of low-income population, the dynamics of employment of persons with higher education.

The article presents some result of empirical research of human potential components, including the analysis of statistical data and some results of sociological research conducted by the survey method in the Volgograd region. In Russia, the demographic situation has improved considerably in recent years, but modern fertility parameters remain problematic. One of these problems is the decline in the number of women aged 20 to 29. In most regions of the Russian Federation, including in the Volgograd region there is a decrease in the population (human potential), including a constant tendency to reduce the population at working age. This situation leads to an increase in the demographic burden. Human potential indicators (employment rate, growth rate of new jobs) have a steady downward trend. In General, Russia is one of the countries with a low unemployment rate, but economic activity is low, due to the wide spread of new forms of employment: freelancing and autstaffing, as well as the precariat, as a layer of workers who work in illegal forms of employment. The positive dynamics of the society's potential is directly related to the level of labor productivity, which is characterized by instability and fluctuations and affects the decrease in motivation to work. The data of empirical research conducted by the author allow to reveal a stable causal relationship: "low wages-low motivation to work - low productivity". The article shows that the development of human potential in Russia and the region under study depends on the size of wages of the working-age population and the level of its differentiation by territorial entities, which is very high. According to an empirical study in the Volgograd region in 2015, more than half of respondents could not meet their needs for quality education, more than $80.0 \%$ - in quality medical care, $90.0 \%$ - in quality recreation.

$\infty \quad$ It is concluded that at present the state and dynamics of the human potential of the Russian society in General, and the Volgograd region in particular, requires efforts to form internal and external factors that can ensure its development and dynamics.
\end{abstract}

Key words: potential of the society, human potential, dynamic potential of the society, the number of ablebodied population, motivation to work, freelance, precariat, differentiation of wages, unbalanced development of human potential in the territory. 
УДК 316.332 .6

ББК 60.55

\title{
ДИНАМИЧЕСКИЙ ПОТЕНЦИАЛ ОБЩЕСТВА
}

\author{
Инна Викторовна Василенко
}

Волгоградский государственный университет, г. Волгоград, Российская Федерация

\begin{abstract}
Аннотация. Актуальность статьи заключается в создании методологических основ исследования потенциала общества страны, региона, как макросоциальной структуры, противоречия внутри которой отрицательно влияют на благополучие населения, его мотивацию и активность. В данной статье уточняется понятие «динамический потенциал общества» как совокупность изменений, происходящих со всеми видами ресурсов и возможностей общества в сторону их увеличения или сокращения. Динамической основой этого потенциала является человеческий потенциал. Он измеряется состоянием численности населения, в том числе трудоспособного населения, уровнем занятости и безработицы, производительности труда и мотивации к труду, степенью дифференциации оплаты труда, долей низкообеспеченного населения, динамикой занятости лиц с высшим профессиональным образованием.

В статье представлены общие результаты эмпирического исследования компонентов человеческого потенциала, включающего анализ статистических данных и некоторых итогов социологического исследования, проведенного методом опроса в Волгоградском регионе. В России за последние годы демографическая ситуация значительно улучшилась, но современные параметры рождаемости остаются проблемными. Одна из этих проблем - снижение численности женщин в возрасте от 20 до 29 лет. В большинстве субъектов РФ, в том числе и в Волгоградской области, происходит сокращение численности населения (человеческого потенциала), в том числе наблюдается постоянная тенденция сокращения численности населения в трудоспособном возрасте. Такая ситуация приводит к росту демографической нагрузки. Показатели использования человеческого потенциала (уровень занятости, темп роста числа новых рабочих мест) имеют устойчивую нисходящую тенденцию. В целом Россия относится к числу государств с невысоким уровнем безработицы населения, однако экономическая активность невысока за счет широкого распространения новых форм занятости: фриланса и аутстаффинга, а также прекариата как слоя работников, которые работают в нелегальных формах занятости. Положительная динамика потенциала общества напрямую связана с уровнем производительности труда, который характеризуется нестабильностью и колебаниями и сказывается на снижении мотивации к труду. Данные эмпирического исследования, проведенного автором, позволяют выявить устойчивую причинно-следственную связь: «низкие зарплаты - низкая мотивация к труду - низкая производительность труда». В статье показывается, что развитие человеческого потенциала в России и исследуемом регионе зависит от размера заработной платы трудоспособного населения и уровня ее дифференциации по территориальным субъектам, которая весьма высока. По данным эмпирического исследования, в Волгоградском регионе в 2015 г. более половины респондентов не могли удовлетворить свои потребности в качественном образовании, более 80,0 \% - в качественном медицинском обслуживании, 90,0 \% - в качественном отдыхе.

Делается вывод, что в настоящее время состояние и динамика человеческого потенциала российского общества в целом (и Волгоградской области в частности) требует усилий для формирования внутренних и внешних факторов, способных обеспечить его развитие и динамику.

Ключевые слова: потенциал общества, человеческий потенциал, динамический потенциал общества, численность трудоспособного населения, мотивация к труду, фриланс, прекариат, дифференциация оплаты труда, несбалансированное развитие человеческого потенциала по территории.
\end{abstract}

\section{Постановка исследовательской задачи}

В развитии социологической науки прослеживается смена научных приоритетов с макросоциологических объектов на микросоциологические, бум эгоцентрических взглядов на общество сменяет моду на социоцентрические подходы. При этом замена, как прави- ло, сопровождается, за редким исключением (П. Бурдье, Э. Гидденс), игнорированием макросоциальных явлений и процессов, снижением их значимости в научной рефлексии социологов. Вместе с тем исследование микросоциальных проблем не может решить противоречий, формирующихся на макроуровне социума. К числу таких проблем относится 
процесс развития общественного потенциала, который обеспечивает устойчивость страны, государства, социума перед внешними вызовами. В связи с этим целью статьи является анализ потенциала российского общества, исследование состояния человеческого потенциала как основной социальной силы, обеспечивающей динамику развития всех подсистем потенциала общества и региона.

\section{Определение основных понятий}

Под потенцией (лат. potentia - сила) понимают возможность, внутренне присущую силу, способность к действию [21, с. 357]. Иными словами, потенция - это покоящаяся, не действующая, но способная к действию сила.

В некоторых источниках потенциал понимается, во-первых, как величина, характеризующая запас энергии физического тела или поля, а во-вторых, как совокупность возможностей в чем-то [19, с. 448].

Под потенциалом понимаются также средства, запасы и возможности, которые могут быть использованы отдельным лицом, обществом, государством в определенной области для достижения определенной цели и решения какой-либо задачи [20, с. 373-374].

Приведенные определения понятия «потенциал» достаточно полно раскрывают заложенный в нем смысл. Ведь для того чтобы постоянно развиваться общественная система должна иметь определенный запас ресурсов, социальных сил. Поэтому «потенциал общества» - это основные внутренние ресурсы общества, позволяющие обеспечить, с одной стороны, неуклонное развитие страны, достижение уровня самых развитых стран, а с другой, ее национальную и экономическую безопасность. Потенциал общества существует в скрытой, не проявляющейся форме, только возможной к актуализации при известных условиях, что и определяет сложность выявления механизма его формирования, воспроизводства и использования. Потенциал общества должен постоянно развиваться, создавать резерв общественных сил в соответствии с происходящими общемировыми и внутригосударственными изменениями, чутко улавливать вновь возникающие тенденции. Это свойство потенциала общества является настолько важным, что мы посчитали целесообразным заострить внимание на нем и далее исследовать потенциал общества в аспекте свойства динамического развития, а сам потенциал общества назвать «динамическим потенциалом общества».

Общественный потенциал общества включает в себя геополитическую, экономическую, социальную, экологическую, культурную и человеческую составляющие [8, с. 77]. Поэтому под динамическим потенциалом общества мы понимаем трансформации, происходящие с геополитическими, экономическими, социальными, экологическими, культурными и человеческими ресурсами и возможностями общества в сторону их увеличения или сокращения, в сторону улучшения качества этих ресурсов или его снижения, происходящие под влиянием внутренних и внешних факторов и сказывающиеся на достижении поставленных целей и задач.

Если речь идет о динамическом потенциале общества, то акцент делается на человеческом потенциале, инициирующем и поддерживающем динамику всех потенциалов, имеющихся в обществе. Человеческий потенциал характеризует качество и жизнеспособность общества, определяет его динамику и перспективы развития, а также объединяет активных, целенаправленных субъектов, действующих под влиянием личных интересов, институциональных норм и ценностей и создающих как будущий, так и текущий потенциал общества, позволяющий выполнять поставленные задачи и цели развития страны, отвечать на внешние вызовы. Поэтому для безопасности и развития любого национального общества в международной конкурентной среде важны общая численность граждан, сбалансированность поколений и гендеров, уровень образования, квалификации, профессионализм работников, а также социокультурные особенности нации, влияющие на ее жизнеспособность. Следовательно, целесообразным представляется анализ человеческого потенциала российского общества и волгоградского региона как примера исследования регионального аспекта.

\section{Результаты анализа человеческого потенциала российского общества и Волгоградской области}

Человеческий потенциал тесным образом связан с численностью населения стра- 
ны. Российская Федерация вошла в XXI в. в условия х устойчивого превышения числа умерших над числом родившихся (депопуляция). В 1999 г. это превышение составило в целом по стране 840 тыс. человек, в 2000 г. 959,0 тыс. человек, а в 2005 г. оно составило 847,0 тыс. человек. Затем положение несколько выправилось. Появилась положительная динамика, которая обеспечивалась за счет снижения естественной убыли населения. В 2007 г. естественный прирост составил 470,0 тыс. человек, в 2009 г. - 249,0 тыс. человек, в 2011 г. - 129,0 тыс. человек, а в 2012 г. - 4,3 тыс. человек. Начиная с 2013 г., отмечается естественный прирост. Он составил 24,0 тыс. человек, в 2014 г. - 30,0 тыс. человек, в 2015 г. - 32,0 тыс. человек. К сожалению, в 2016 г. снова отмечается естественная убыль - 2,3 тыс. человек [6]. Причинами естественного прироста с 2013 по 2015 г. являлось, и это подтверждают статистические данные, увеличение уровня рождаемости в России с 1610,1 тыс. родившихся в 2007 г. (начало реализации мер пронаталисткой политики) до 1 941,0 тыс. родившихся в 2015 г. - увеличение произошло в 1,2 раза. Изменение тенденции с роста на естественную убыль происходило постепенно, как за счет снижения темпов прироста рождаемости, так и за счет увеличения темпов прироста смертности. Так, с 2014 по 2015 г. темп прироста рождаемости составил 2,1 тыс. человек, а темп прироста смертности - 3,8 тыс. человек [6].

На современную ситуацию рождаемости в стране повлияли такие факторы, как снижение числа женщин в возрасте от 20 до 29 лет, а также ухудшение международной обстановки и политических отношений со странами Западной Европы и США в последние годы.

Несмотря на то что в России за последние годы демографическая ситуация значительно улучшилась, современные параметры рождаемости остаются проблемными. В 2017 г. в среднем на одну женщину приходилось 1,78 рождения при 2,22, необходимых для простого воспроизводства населения [7, с. 28].

Проблемной остается сокращение численности населения в большинстве субъектов РФ. В 2016 г. только в столичных и нефтегазовых субъектах, а также в части кавказских республик не произошло сокращение численности. Население выросло более чем на 11,0 \% в девяти субъектах, а сократилось более чем на $11,0 \%$ в тридцати семи субъектах России [12].

За период с 2015 по 2016 г. в Волгоградской области, так же, как и в Самарской, Саратовской, Ростовской, Ярославской, Омской и Костромской областях существенно снизилась численность населения. Увеличилась численность в Москве, Санкт-Петербурге, Новосибирске, Московской области, Свердловской области, Ставропольском крае и Тюменской области [34].

На 1 января 2011 г. численность Волгоградской области составляла 2,608 млн человек, на 1 января 2018 г. численность Волгоградской области снизилась до 2,521 млн человек [16].

Таким образом, ситуация с численностью населения России и многих регионов неуклонно ухудшается.

Следующим показателем величины человеческого потенциала является численность трудоспособного населения. По прогнозам специалистов, в течение ближайших 10 лет (2014-2023 гг.) вступать в этот контингент будет в среднем ежегодно по полтора миллиона человек, тогда как выбывать по два с половиной миллиона человек [26]. Согласно расчетам Минэкономразвития РФ, численность россиян трудоспособного возраста в 2015 г. с учетом Крыма, по предварительным данным, составляла 84,7 млн человек, в 2016 г. она снизилась до 83,7 млн человек [35]. На основе прогнозов Минэкономразвития РФ на 2019-2020 гг. численность трудоспособного населения уменьшится в 2018 г. до 81,8 млн, в 2019 г. - до 81,1 млн [23, с. 27].

Вывод: наблюдается постоянная тенденция сокращения численности населения в трудоспособном возрасте. Такая ситуация способна привести к росту демографической нагрузки с 730 нетрудоспособных на 1000 лиц трудоспособного возраста в 2015 г. до 820 в 2019 году.

В Волгоградской области ситуация обстоит не лучше. Так, если в 2007 г. численность трудоспособного населения составляла 1,691 млн человек, то на 1 января 2017 г. она сократилась до 1,495 млн человек. По- 
скольку часть трудоспособного населения учится или не занята в экономике, то необходимо рассмотреть динамику изменения численности в экономике населения Волгоградской области. Если в 2007 г. занятых было 1,258 млн человек, то в 2016 г. 1,148 млн человек [2]. Таким образом, темп сокращения численности с 2007 г. составил 82 тыс. человек.

Следствием является снижение мотивации к труду, удовлетворенности трудом, потребности в формировании качественного человеческого потенциала.

Качество человеческого, а в частности трудового потенциала в последнее время заметно снижается. Это происходит за счет не полной включенности населения в трудовую деятельность (в Волгоградской области 248 тыс. трудоспособного населения не занято в экономике) [2] по причине значительной дифференциации в оплате труда и невысоких среднедушевых доходов (в Волгоградской области они составляют за последние два года чуть выше 21 тыс. рублей) [2], невысокого уровня производительности труда и сниженной мотивации к труду.

Основными показателями использования человеческого потенциала являются уровень безработииы и темп создания новых рабочих мест. Уровень безработицы в РФ начал повышаться с 2015 г. и составил 5,6\%, а в 2016 г. $-5,8 \%$, что связано с реакцией экономики на экономический кризис последних лет и санкционную политику в отношении России со стороны европейских стран и США. Обе тенденции имеют отрицательный характер и негативно сказываются на формировании динамического потенциала общества. Уровень регистрируемой безработицы в Волгоградской области составил на 1 июня 2016 г. 1,08 \% [32]. Такой уровень безработицы, вместе с тем, не означает благополучного положения на рынке труда. Скорее всего он связан с тем, что волгоградцы, особенно молодежь, предпочитают искать себе рабочее место за пределами своего города.

В целом Россия относится к числу государств с невысоким уровнем безработицы населения. Однако следует учитывать, что российское общество отличается наличием заметного социального, экономического и культурного расслоения между регионами как субъектами федерации.

Известно, что для развития страны и регионов нужен запас прочности для позитивной динамики, а в сфере занятости это как минимум $15 \%$ темп создания новых рабочих мест $[3$, c. 3]. Это темп обновления, темп спроса на человеческий потенциал. Все развитые страны - США, Германия - идут с темпом примерно в $15 \%$, Китай, многие другие страны с динамичной экономикой развивались с темпом создания рабочих мест 19-21 \% в год. Российская Федерация существенно отстает [13].

Следствием является широкое распространение работы в новых формах занятости: по устной договоренности (аутстаффинг, фрилансерство), а также недозанятости и занятости в личных подсобных хозяйствах и т. д. По данным исследования, проведенного аналитическим сервисом Primelance.com в 2017 г., фриланс-рынок в России включает 704430 человек [14].

Еще одним проблемным явлением является прекаризация. Ж.Т. Тощенко считает, что прекариат - это новый социальный класс, который олицетворяет отчуждение не только от результатов труда, но и от всего общества значительных социальных групп, испытывающих особо изощренные формы эксплуатации их труда, их знаний, их квалификации, а, в конечном счете, и качества жизни [31].

Под прекаризацией понимают также процессы коррозии назначения труда в обществе, системы защищенной занятости, вследствие чего появляются проблемы профессиональной интеграции, индивидуального/семейного существования работников и общественной мобилизации, угрожающие развитию современного общества [27, с. 21]. Эти группы широко распространены во всех странах мира. Их доля колеблется от 30 до $40 \%$ [11].

Не случайно в 2013 г. в рамках XIV Апрельской конференции ВШЭ состоялось пленарное заседание «Институты и новая социальная политика», на котором вице-премьер Ольга Голодец, куратор социального блока в правительстве, сделала акцент на проблемах развития рынка труда. «Тут накопилась масса негативных явлений, - сказала вице-премьер. В России из 86 млн граждан трудоспособного возраста только 48 млн работают в секторах, 


\section{СОЦИОЛОГИЯ И СОЦИАЛЬНЫЕ ТЕХНОЛОГИИ}

которые нам видны и понятны. Где и чем заняты все остальные, мы не понимаем?» [15].

Описанная ситуация в сфере трудовых отношений приводит к недоиспользованию труда в России. В 2010 г., например, объем недоиспользованного труда в РФ составил 9,8 млн человек, в 2015 г. - около 7,8 млн человек $[18$, с. 65$]$. Все эти тенденции опасны для формирования человеческого потенциала российского общества как в количественном, так и в качественном отношении.

Выше уже отмечалось, что положительная динамика потенциала общества напрямую связана с уровнем производительности $m p y d a$, который характеризуется явной нестабильностью и колебаниями. К примеру, производительность труда в России за период 2005-2007 гг. имела тенденцию к росту. 2008 и 2009 гг. отличились заметным снижением производительности труда на 3-4 \%. В дальнейшем темпы роста повысились, но, к сожалению, не смогли достичь уровня 2007 года. Во многом это объясняется снижением темпов роста производительности труда. Так, в 2005 г. темп роста составил 5,5\%, в $2006-$ $7,5 \%$, в $2010-3,3 \%$, в $2014-0,9 \%$ [1, с. 73]. При этом показатель производительности труда в России составляет $26,9 \%$ от показателя США, 39,8 \% от Японии и Германии, 33,3\% от Франции, 36,2 \% от Швеции. По темпам роста производительности труда Россия отстает от таких стран, как Китай и даже Бразилия [22]. В то же время есть некоторые позитивные изменения этого показателя. В Волгоградской области наметился некоторый рост уровня производительности труда. Производительность труда на ведущих промышленных предприятиях и организациях Волгоградской области увеличилась в 1-м полугодии
2017 г. на 11,2 \% по отношению к аналогичному периоду 2016 г. [9].

Уровень производительности труда определяется уровнем мотивации к труду. Каковы основные характеристики и динамика мотивации к труду? Рассмотрим результаты социологического исследования, проведенного под руководством автора, методом анкетирования в июне-июле 2015 г. в Волгограде $(N=620)$, тип выборки - маршрутно-квотный (квотирование осуществлялось по полу и возрасту). Ошибка выборки $- \pm 4,1 \%$.

Опрос жителей Волгограда и ряда районов волгоградской области (лето 2015 г.) показал, что труд является единственным источником существования $(87,9 \%$ респондентов), а главным мотивом к труду называется размер заработной платы. Он важен для $68,8 \%$ опрошенных. При этом важность реализации своих способностей отметили 4,0 \%, а содержания труда $-12,4 \%$. Таким образом, материальная сторона труда становится определяющей в формировании мотивации отношения к труду, зачастую в противовес профессиональным амбициям и успеху.

Исследование также показало, что, по мнению респондентов, человек может добиться успеха в современном мире благодаря таким качествам человеческого потенциала, как: наличие знакомств и связей $(36,0 \%)$, упорная работа (28,0 \%) (см. таблицу).

Гораздо меньше успеху способствуют хорошее образование и талант. Результаты регионального исследования подтверждаются рядом исследований социологов и психологов, которые однозначно утверждают, что основной мотив к труду - это уровень заработной платы [24, с. 60].

Таким образом, на настоящий момент сформирована устойчивая причинно-след-

Качества, позволяющие добиться успеха, по мнению респондентов

\begin{tabular}{|l|c|c|c|c|}
\hline \multicolumn{1}{|c|}{ Качество личности } & Частота & Процент & $\begin{array}{c}\text { Валидный } \\
\text { процент }\end{array}$ & $\begin{array}{c}\text { Кумулятивный } \\
\text { процент }\end{array}$ \\
\hline Наличие знакомства и связей & 223 & 36,0 & 36,0 & 36,0 \\
\hline Упорная работа & 173 & 28,0 & 28,0 & 64,0 \\
\hline Хорошее образование & 88 & 14,0 & 14,0 & 78,0 \\
\hline $\begin{array}{l}\text { Умение идти напролом, добиваться } \\
\text { своих целей любой ценой }\end{array}$ & 74 & 12,0 & 12,0 & 94,0 \\
\hline Везение, случай & 37 & 6,0 & 6,0 & 100,0 \\
\hline Талант, способности & 25 & 4,0 & 4,0 & 82,0 \\
\hline Итого & 620 & 100,0 & 100,0 & - \\
\hline
\end{tabular}


ственная связь: «низкие зарплаты - низкая мотивация к труду - низкая производительность труда», следствием которой является масштабная демотивация населения к продуктивному труду. В основе этой демотивации лежит неверие в эффективность использования способностей и профессионализма работника и возрастающая дифференциация по доходам.

В практике трудовых отношений между работниками и работодателями возникает множество проблем по оплате труда. В частности, работники считают, что работодатели зачастую несправедливо оплачивают труд работников, материально их недооценивают. Действительно, исследуя размер оплаты труда работников разных профессий, можно заметить, что существует значительный уровень дифференциации в размере зарплат.

В соответствии с оценками Росстата, доля доходов, приходящихся на 20 \% наиболее обеспеченных граждан, по итогам 2017 г. составила $47,0 \%$, а доля доходов 20 \% наименее обеспеченных - 5,3\% от общего объема. Практически те же показатели наблюдались в 2016 г. (47,1 \% и 5,3\% соответственно) $[17$, с. 10].

Среднемесячная номинальная начисленная заработная плата работников в целом по экономике России в январе-феврале 2018 г. составила соответственно 39,0 и 40,4 тыс. рублей [29]. Среднемесячная начисленная заработная плата за декабрь 2017 г. в крупных, средних и малых организациях Волгоградской области ниже среднего уровня и составила 35,3 тыс. рублей [28].

Заработная плата специалистов высшего уровня квалификации колеблется по округам от 13436 в до 30443 рублей, специалистов среднего уровня изменяется в диапазоне от 10692 до 21792 рублей. Разрыв в уровне заработной платы по Федеральным округам с учетом профессиональных групп колеблется от 1,7 до 2,5 раза [4].

К примеру, по результатам исследования пяти регионов России, проведенного научноучебной лабораторией анализа и моделирования институциональной динамики НИУ ВШЭ, с одной стороны, зарплата воспитателей детских садов за год увеличилась сразу в 2,5 раза, но, с другой - разброс по регионам очень большой - от 27 тысяч до 80 [15].

В Волгоградской области также наблюдается дифференциация в заработной плате среди работников педагогических профессиональных групп. Так, средняя заработная плата педагогических работников муниципальных образовательных организаций в муниципальных районах (городских округах) Волгоградской области за январь-декабрь 2017 г. варьировала от 19,6 тыс. рублей до 27,5 тыс. рублей; педагогических работников общеобразовательных организаций - от 22,4 тыс. рублей до 28,8 тыс. рублей; учителей - от 22,8 тыс. рублей до 29,4 тыс. рублей [5].

В таких условиях формирование качественного человеческого потенциала крайне затруднено, причем не только за счет внешних факторов (низкой заработной платы), но и изза внутренних (неудовлетворенность работой и жизнью).

Такая ситуация приводит к тому, что по данным нашего исследования в 2015 г. не могли удовлетворить свои потребности в качественном образовании 52,6 \%, качественном медицинском обслуживании $-84,8$ \%, качественном отдыхе - 90,2 \% опрошенных. Эти данные подтверждаются статистической информацией.

Численность населения с денежными доходами ниже величины прожиточного минимума в России в первом квартале 2016 г. выросла до 22,8 млн человек по сравнению с 14,5 млн в четвертом квартале 2015 г. [36]. В апреле 2017 г. этот показатель составил 21,3 млн человек (величина прожиточного минимума - 10328 рублей) [33]. С точки зрения россиян, главные причины бедности низкая зарплата $(65,2$ \%), недостаточность государственных пособий по социальному обеспечению (37,3 \%), невыплата зарплаты (34,5 \%). В Волгоградской области ниже прожиточного минимума живет $15,1 \%$ [2, с. 69]. Иными словами, 382 тыс. человек живут за чертой бедности.

Еще одним показателем качества человеческого потенциала и возможности его положительной динамики является доля лиц с высшим профессиональным образованием и их активность в экономике. Здесь наблюдаются две тенденции. Во-первых, за последние 
годы наблюдается сокращение числа специалистов с высшим профессиональным образованием (с 2010 по 2016 г. в России в 1,3 раза) [25, с. 146]. Во-вторых, в 2016 г. уровень занятых с высшим образованием составил $33,0 \%$ [10]. Значительная часть занятого населения с профессиональным образованием концентрируется в Центральном федеральном округе (3 750 человек на 10 тыс. занятого населения с высшим образованием). На остальных территориях представительство высококвалифицированных специалистов с высшим образованием сравнительно меньше. В Волгоградской области в 2016 г. доля занятых в экономике с высшим образованием приближается к среднему уровню и составляет $33,6 \%$ [30, c. 114$]$.

Таким образом, можно говорить о концентрации человеческого капитала высокого качества в основном в Москве. При этом регионы оказываются в ситуации дефицита высококвалифицированных кадров.

В этих условиях стратегически необходимо развивать человеческий потенциал российских регионов, обеспечить более равномерное развитие всех субъектов Российской Федерации по перечисленным выше показателям, а также:

- организовать более жесткий учет официально неработающего населения;

- способствовать развитию малого и среднего бизнеса, оказывать поддержку на федеральном и региональном уровнях;

- внедрить правовое регулирование деятельности фрилансеров и сделать прозрачным деятельность работодателей, способствующих развитию прекариата в России;

- использовать культурные, образовательные и воспитательные источники для поиска внутренних (ментальных) и внешних источников роста и реализации человеческого потенциала, определяющего осознанное терминальное отношение населения к труду.

\section{СПИСОК ЛИТЕРАТУРЫ}

1. Васнев, С. А. Производительность труда: анализ динамики в ключевых отраслях российской экономики / С. А. Васнев, Н. Н. Васнева // Между- народный научный журнал «Инновационная наука». - 2016. - № 4. - С. 72-78.

2. Волгоградская область в цифрах. 2016 : краткий сб. / Террит. орган Федер. службы гос. статистики по Волгоград. обл. - Волгоград : Волгоградстат, 2017. $368 \mathrm{c}$.

3. Гимпельсон, В. Е. Движение рабочих мест в российской экономике: в поисках созидательного разрушения : препринт WP3/2012/03 / В. Е. Гимпельсон, Р. И. Капелюшников, 3. А. Рыжикова. - М. : Изд. дом Высшей школы экономики, 2012. - 45 с.

4. Дифференциация заработной платы работников по профессиональным группам. - Электрон. текстовые дан. - Режим доступа: http:/www.gks.ru/ bgd/regl/B12_04/IssWWW.exe/Stg/d06/3-plat.htm (дата обращения: 23.04.2018). - Загл. с экрана.

5. Ежеквартальный мониторинг эффективности деятельности органов местного самоуправления городских округов и муниципальных районов Волгоградской области за 2017 год. - Электрон. текстовые дан. - Режим доступа: http://economics. volgograd.ru/docs/otdelanaliza/!\%D0\%98 \%D0\%B D\%D $1 \% 84 \%$ D0\%BE\%D 1\%80\%D0\%BC\%D0\% B0\%D1\%86\%D0\%B8\%D1\%8F_4\%20\%D0\%BA\%D0 $\% \mathrm{~B} 2 \% \mathrm{D} 0 \% \mathrm{~B} 0 \% \mathrm{D} 1 \% 80 \% \mathrm{D} 1 \% 82 \% \mathrm{D} 0 \% \mathrm{~B} 0 \% \mathrm{D} 0 \% \mathrm{BB} . \mathrm{pdf}$ (дата обращения: 23.04.2018). - Загл. с экрана .

6. Естественное движение населения. - Электрон. текстовые дан. - Режим доступа: http:// www.gks.ru/wps/wcm/connect/rosstat_main/rosstat/ ru/statistics/population/demography/\# (дата обращения: 23.04.2018). - Загл. с экрана.

7. Женщины и мужчины России. 2016 : стат. сб. / Росстат. - М., 2016. - 208 с.

8. Заславская, Т. И. Динамика человеческого потенциала / Т. И. Заславская // Россия, которую мы обретаем / отв. ред. Т. И. Заславская, 3. И. Калугина. - Новосибирск : Наука, 2003. - С. 75-93.

9. Зубкова, Т. Волгоградские предприятия увеличивают производительность труда. - Электрон. текстовые дан. - Режим доступа: http://www.volgograd.ru /news/154432/ (дата обращения: 23.04.2018). - Загл. с экрана.

10. Индикаторы образования: 2017 : стат. сб. // Высшая школа экономики. - Электрон. текстовые дан. - Режим доступа: https://www.hse.ru /primarydata/io2017 (дата обращения: 23.04.2018). Загл. с экрана.

11. Королева, А. Вместе против налогов // Эксперт Online. - Электрон. текстовые дан. - Режим доступа: http://expert.ru/2013/04/4/vmeste-protiv-nalogov (дата обращения: 23.04.2018). - Загл. с экрана.

12. Кравченко, Л. И. Демографическая ситуация в России - 2016. - Электрон. текстовые дан. Режим доступа: http://rusrand.ru/analytics /demograficheskaya-situaciya-v-rossii--2016 (дата обращения: 23.04.2018). - Загл. с экрана. 
13. Красноярский экономический форум: выступление Владимира Гимпельсона. - Электрон. текстовые дан.- Режим доступа: https://www.hse.ru /expertise/news/177478566.html (дата обращения: 23.04.2018). - Загл. с экрана.

14. Мамчуева, О. Фриланс-рынок в России в 2017 году - инфографика. - Электрон. текстовые дан. - Режим доступа: https://www.searchengines.ru /itogi-goda-dlya-frilansa-v-rossii.html (дата обращения: 23.04.2018). - Загл. с экрана.

15. Материалы заседаний семинара в 2013/2014 году / Институт образования НИУ ВШЭ. - Электрон. текстовые дан. - Режим доступа: https:// ioe.hse.ru/seminar1314 (дата обращения: 23.04.2018). Загл. с экрана.

16. Население: Волгоградстат. Оценка численности населения Волгоградской области на 1 января 2011-2018 гг. - Электрон. текстовые дан. - Режим доступа: http://volgastat.gks.ru/wps/wcm/ connect/rosstat_ts/volgastat/ru/statistics/population/ (дата обращения: 23.04.2018). - Загл. с экрана.

17. Население России в 2017 году: доходы, расходы и социальное самочувствие. Мониторинг НИУ ВШЭ. - Электрон. текстовые дан. - Режим доступа: https://isp.hse.ru/news/216918439.html (дата обращения: 23.04.2018). - Загл. с экрана.

18. Облаухова, М. В. Об эффективности использования трудовых ресурсов в современной российской экономике / М. В. Облаухова, Н. Л. Казначеева // Вестник Томского государственного университета. Экономика. - 2016. № 1 (33). - С. 54-66.

19. Потенциал // Большой словарь иностранных слов / сост. А. Ю. Москвин. - М. : Центрополиграф, 2008.- С. 448.

20. Потенциал // Словарь иностранных слов и выражений.-М. : Олимп : АСТ-ЛТД, 1997.-С. 373-374.

21. Потенция // Философский энциклопедический словарь. - М. : ИНФРА-М, 1999. - С. 357.

22. Правительство хочет увеличить производительность труда на 50 \% за пять лет. - Электрон. текстовые дан. - Режим доступа: http://www.newsru.com /finance/10dec2013/proizvoditelnost.html (дата обращения: 23.04.2018). - Загл. с экрана.

23. Прогноз социально-экономического развития Российской Федерации на 2018 и на плановый период 2019 и 2020 годов. - Электрон. текстовые дан. - Режим доступа: http:/economy.gov.ru/wps/ wcm/connect/2e83e62b-ebc6-4570-9d7b-ae0beba79f63/ prognoz2018_2020.pdf?mod=ajperes (дата обращения: 23.04.2018). - Загл. с экрана.

24. Прохорова, М. В. Возрастная динамика внутренней и внешней мотивации трудовой деятельности / М. В. Прохорова, В. М. Прохоров // Вестник ЮУрГУ. Серия «Психология». - 2015. - Т. 8, № 3.C. 57-64.
25. Россия в цифрах. 2016 год : крат. стат. сб. М. : Федеральная служба государственной статистики, 2016. $-543 \mathrm{c}$.

26. Рыбаковский, Л. Л. Демографические вызовы: что ожидает Россию? / Л. Л. Рыбаковский. Электрон. текстовые дан. - Режим доступа: http:// rybakovsky.ru/demografia8.html (дата обращения: 23.04.2018). - Загл. с экрана.

27. Сизова, И. Л. Прекаризация в трудовой сфере России. - Электрон. текстовые дан. - Режим доступа: http://socinst.ru/sites/default/files/files/ Sizova_Prekarizatsiya.pdf (дата обращения: 23.04.2018). - Загл. с экрана.

28. Среднемесячная начисленная заработная плата работников организаций по видам экономической деятельности. - Электрон. текстовые дан. Режим доступа: http://volgastat.gks.ru/wps/wcm/ connect/rosstat_ts/volgastat/resources/e0a1d0004 23fb2bb9817be2a5af2b9f7/\%D0\%B7\%D0\%B0\%D1 $\% 80 \% \mathrm{D} 0 \% \mathrm{BF} \% \mathrm{D} 0 \% \mathrm{BB} \% \mathrm{D} 0 \% \mathrm{~B} 0 \% \mathrm{D} 1 \% 82 \% \mathrm{D} 0 \% \mathrm{~B} 0 \_1$ 5082017.htm (дата обращения: 23.04.2018). - Загл. с экрана.

29. Среднемесячная начисленная номинальная и реальная заработная плата работников организаций. Официальная статистика. - Электрон. текстовые дан. - Режим доступа: http://www.gks.ru/wps/ wcm/connect/rosstat_main/rosstat/ru/statistics/wages/ (дата обращения: 23.04.2018). - Загл. с экрана.

30. Статистический ежегодник Волгоградская область 2016 : сборник / Террит. орган Федер. службы гос. статистики по Волгогр. обл. - Волгоград : Волгоградстат, 2017. - 800 с.

31. Тощенко, Ж. Т. Прекариат - новый социальный класс / Ж.Т. Тощенко // Социологические исследования. - 2015. - № 6. - С. 3-13.

32. Уровень безработицы Волгоградской области снизился на 1 \%. - Электрон. текстовые дан. Режим доступа: http://riac34.ru/news/70740/ (дата обращения: 23.04.2018). - Загл. с экрана.

33. Федеральная служба государственной статистики. Официальная статистика. Заработная плата. - Электрон. текстовые дан. - Режим доступа: http://www.gks.ru/wps/wcm/connect/rosstat main /rosstat/ru/statistics/wages/labour_costs/ (дата обращения: 11.05.2018). - Загл. с экрана.

34. Численность населения по субъектам Российской Федерации. - Электрон. текстовые дан. - Режим доступа: https://uisrussia.msu.ru/stat/Publications /Ejeg2016/Ejeg2016_04_Ejeg2016_04_030.htm (дата обращения: 23.04.2018). - Загл. с экрана.

35. Численность россиян трудоспособного возраста снизится за 5 лет на 3,6 млн-Минэкономразвитие // Финмаркет. - Электрон. текстовые дан. Режим доступа: http://www.finmarket.ru/themes /demography/?sec=\&id=4277703 (дата обращения: 23.04.2018). - Загл. с экрана. 
36. Число бедных в России выросло до 23 миллионов человек. - Электрон. текстовые дан. - Режим доступа: https://lenta.ru/news/2016/ 06/17/poverty/ (дата обращения: 23.04.2018). - Загл. с экрана.

\section{REFERENCES}

1. Vasnev S.A., Vasneva N.N. Proizvoditelnost truda: analiz dinamiki v klyuchevykh otraslyakh rossiyskoy ekonomiki [Labour Productivity: Analysis of Dynamics in Key Sectors of the Russian Economy]. Mezhdunarodnyy nauchnyy zhurnal "Innovatsionnaya nauka”, 2016, no. 4, pp. 72-78.

2. Volgogradskaya oblast v tsifrakh. 2016: kratkiy sb. [The Volgograd Region in Figures. 2016: Brief Compilation]. Territorial Body of State Statistics Federal Service in the Volgograd Region. Volgograd, Volgogradstat Publ., 2017.368 p.

3. Gimpelson V.E., Kapelyushnikov R.I., Ryzhikova Z.A. Dvizhenie rabochikh mest v rossiyskoy ekonomike: v poiskakh sozidatelnogo razrusheniya: preprint WP3/2012/03 [The Movement of Jobs in the Russian Economy: in Search of Creative Destruction. Preprint WP3/2012/03/]. Moscow, NII VShE Publ., 2012. 45 p.

4. Differentsiatsiya zarabotnoy platy rabotnikov po professionalnym gruppam [Differentiation of Employees' Wages by Occupational Groups]. URL: http://www.gks.ru/bgd/regl/B12_04/IssWWW.exe/Stg/ d06/3-plat.htm. (accessed 23 April 2018).

5. Ezhekvartalnyy monitoring effektivnosti deyatelnosti organov mestnogo samoupravleniya gorodskikh okrugov i munitsipalnykh rayonov Volgogradskoy oblasti za 2017 god [Quarterly Monitoring of Efficiency of Local Governments of City Districts and Municipal Districts of the Volgograd Region for 2017]. URL: http://economics.volgograd.ru/ docs/otdelanaliza/!\%D0 \%98 \% D0\%BD\%D1 \%84 $\%$ D0 \%BE $\%$ D $1 \% 80 \%$ D0\%BC\%D0\%B0\%D 1 $\% 86 \%$ D0\%B8\%D1\%8F_4\%20\%D0\%BA\% D0 $\% \mathrm{~B} 2 \% \mathrm{D} 0 \% \mathrm{~B} 0 \% \mathrm{D} 1 \% 80 \% \mathrm{D} 1 \% 82 \% \mathrm{D} 0 \% \mathrm{~B} 0 \% \mathrm{D} 0 \% \mathrm{BB} . \mathrm{pdf}$. (accessed 23 April 2018).

6. Estestvennoe dvizhenie naseleniya [The Natural Movement of Population]. URL: http://www.gks.ru/wps/ wcm/connect/rosstat_main/rosstat/ru/statistics/ population/demography/\# (accessed 23 April 2018).

7. Zhenshchiny i muzhchiny Rossii. 2016: Stat. $s b$. [Women and Men of Russia. 2016. Collected Statistics]. Moscow, Russian State Statistics Service, 2016. 208 p.

8. Zaslavskaya T.I. Dinamika chelovecheskogo potentsiala [Dynamics of Human Potential]. Zaslavskaya T.I., Kalugina Z.I., eds. Rossiya, кotoruyu my obretaem [Russia Which We Acquire]. Novosibirsk, Nauka Publ., 2003, pp. 75-93.
9. Zubkova T. Volgogradskie predpriyatiya uvelichivayut proizvoditelnost truda [Volgograd Enterprises Increase Productivity]. URL: http:// www.volgograd.ru/news/154432/. (accessed 23 April 2018).

10. Indikatory obrazovaniya: 2017 . Statisticheskiy sbornik [Indicators of Education, 2017. Statistical Compilation]. Vysshaya shkola ekonomiki [Higher School of Economics]. URL: https://www.hse.ru/ primarydata/io2017. (accessed 23 April 2018).

11. Koroleva A. Vmeste protiv nalogov [Together Against Taxes]. URL: http://expert.ru/2013/04/4/ vmeste-protiv-nalogov. (accessed 23 April 2018).

12. Kravchenko L.I. Demograficheskaya situatsiya $v$ Rossii-2016 [Demographic Situation in Russia - 2016]. URL: http://rusrand.ru/analytics/ demograficheskaya-situaciya-v-rossii--2016. (accessed 23 April 2018).

13. Krasnoyarskiy ekonomicheskiy forum: vystuplenie Vladimira Gimpelsona [The Krasnoyarsk Economic Forum: Speech by Vladimir Gimpelson]. URL: https://www.hse.ru/expertise/news/177478566.html (accessed 23 April 2018).

14. Mamchueva O. Frilans-rynokv Rossii v 2017 godu - infografika [The Freelance Market in Russia in 2017 - Infographics]. URL: https:// www.searchengines.ru/itogi-goda-dlya-frilansa-vrossii.html (accessed 23 April 2018).

15. Materialy zasedaniy seminara v 2013/2014 godu [The Proceedings of Seminar in 2013-2014]. URL: https://ioe.hse.ru/seminar1314 (accessed 23 April 2018).

16. Naselenie: Volgogradstat. Otsenka chislennosti naseleniya Volgogradskoy oblasti na 1 yanvarya 20112018 gg. [Population. Volgograd State Statistics Service. Estimation of Population of the Volgograd Region as of January 1, 2011-2018]. Territorial Body of State Statistics Federal Service in the Volgograd Region. URL: http:// volgastat.gks.ru/wps/wcm/connect/rosstat_ts/ volgastat/ru/statistics/ (accessed 23 April 2018).

17. Naselenie Rossii v 2017 godu: dokhody, raskhody i sotsialnoe samochuvstvie. Monitoring NIU VShE [The Population of Russia in 2017: Revenues, Costs and the Social Well-Being. Monitoring by Higher School of Economics]. URL: https://isp.hse.ru/ news/216918439.html (accessed 23 April 2018).

18. Oblaukhova M.V., Kaznacheeva N.L. $\mathrm{Ob}$ effektivnosti ispolzovaniya trudovykh resursov $\mathrm{v}$ sovremennoy rossiyskoy ekonomike [About Efficiency of Using Manpower in Modern Russian Economy]. Vestnik Tomskogo gosudarstvennogo universiteta. Ekonomika, 2016, no. 1 (33), pp. 54-66.

19. Potentsial [Potential]. Moskvin A.Yu., ed. Bolshoy slovar inostrannykh slov [Large Dictionary of Foreign Words]. Moscow, ZAO Tsentropoligraf Publ., 2008, p. 448.

20. Potentsial [Potential]. Slovar inostrannykh slov $i$ vyrazheniy [Dictionary of Foreign Words and 
Expressions]. Moscow, Olimp Publ.; AST-LTD Publ., 1997, pp. 373-374.

21. Potentsiya [Potency]. Filosofskiy entsiklopedicheskiy slovar [Encyclopedic Dictionary of Philosophy]. Moscow, INFRA-M Publ., 1999, p. 357.

22. Pravitelstvo khochet uvelichit proizvoditelnost truda na $50 \%$ za pyat let [The Government Wants to Increase Labor Productivity by $50 \%$ in Five Years]. URL: http://www.newsru.com/finance/10 dec2013/ proizvoditelnost.html (accessed 23 April 2018).

23. Prognoz sotsialno-economicheskogo razvitiya Rossiyskoy Federatsii na 2018 i na planovyy period 2019 i 2020 godov [Forecast of Socio-Economic Development of the Russian Federation for 2018 and for the Planning Period of 2019 and 2020]. URL: http:// economy.gov.ru/wps/wcm/connect/2e83e62b-ebc6-45709d7b-ae0beba79f63/prognoz2018_2020.pdf?mod=ajperes (accessed 23 April 2018).

24. Prokhorova M.V., Prokhorov V.M. Vozrastnaya dinamika vnutrenney i vneshney motivatsii trudovoy deyatelnosti [Age Dynamics of Internal and External Motivation of Labor Activity]. Vestnik $\mathrm{YuUrGU}$. Seriya «Psikhologiya», 2015, vol. 8, no. 3, pp. 57-64.

25. Rossiya $v$ tsifrakh. 2016 god: kratkiy statisticheskiy sbornik [Russia in Figures. 2016: Brief Compilation of Statistical Data]. Moscow, Federalnaya sluzhba gosudarstvennoy statistiki Publ., 2016. 543 p.

26. Rybakovskiy L.L. Demograficheskie vyzovy: chto ozhidaet Rossiyu? [Demographic Challenges: What does Russia Expect?]. URL: http://rybakovsky.ru/ demografia8a4.html (accessed April 23, 2018).

27. Sizova I.L. Prekarizatsiya v trudovoy sfere Rossii [Precarious Work in the Labour Sphere of Russia]. URL: http://socinst.ru/sites/default/files/files/ Sizova_Prekarizatsiya.pdf (accessed 23 April 2018).

28. Srednemesyachnaya nachislennaya zarabotnaya plata rabotnikov organizatsiy po vidam ekonomicheskoy deyatelnosti [Average Monthly Accrued Wages of Employees by the Types of Economic Activity]. URL: http://economics.volgograd.ru/docs/ otdelanaliza/!\%D0\%98\%D0\%BD\%D1\%84\%D0\%BE $\% \mathrm{D} 1 \% 80 \% \mathrm{D} 0 \% \mathrm{BC} \% \mathrm{D} 0 \% \mathrm{~B} 0 \% \mathrm{D} 1 \% 86 \% \mathrm{D} 0 \% \mathrm{~B} 8 \% \mathrm{D}$ $1 \% 8$ F_4\%20\%D0\%BA \% D \% B $\%$ D $0 \%$ B 0
$\% \mathrm{D} 1 \% 80 \% \mathrm{D} 1 \% 82 \% \mathrm{D} 0 \% \mathrm{~B} 0 \% \mathrm{D} 0 \% \mathrm{BB} \cdot \mathrm{pdf}$ (accessed 23 April 2018).

29. Srednemesyachnaya nachislennaya nominalnaya $i$ realnaya zarabotnaya plata rabotnikov organizatsiy. Ofitsialnaya statistika [Average Monthly Accrued Nominal and Real Wages of Employees. Official Statistics]. URL: http:// www.gks.ru/wps/wcm/connect/rosstat_main/rosstat/ ru/statistics/wages/ (accessed 23 April 2018).

30. Statisticheskiy ezhegodnik Volgogradskoy oblasti 2016: sbornik [Statistical Yearbook of the Volgograd Region, 2016. Collected Data]. Territorial Body of State Statistics Federal Service in the Volgograd Region. Volgograd, Volgogradstat Publ., 2017. 800 p.

31. Toshchenko Zh.T. Prekariat - novyy sotsialnyy klass [Precariat is a New Social Class]. Sotsiologicheskie issledovaniya, 2015, no. 6, pp. 3-13.

32. Uroven bezrabotitsy Volgogradskoy oblasti snizilsya na 1\% [The Unemployment Rate in the Volgograd Region Decreased by 1\%]. URL: http:// riac34.ru/news/70740/ (accessed 23 April 2018).

33. Federalnaya sluzhba gosudarstvennoy statistiki. Ofitsialnaya statistika. Zarabotnaya plata [Federal State Statistics Service. Official Statistics. Wages]. URL: http://www.gks.ru (accessed 11 May2018).

34. Chislennost naseleniya po subyektam Rossiyskoy Federatsii [The Population Size of the Constituent Entities of the Russian Federation]. URL: https://uisrussia.msu.ru/stat/Publications/Ejeg2016/ Ejeg2016_04_Ejeg2016_04_030.htm (accessed 23 April 2018).

35. Chislennost rossiyan trudosposobnogo vozrasta snizitsya za 5 let na 3,6 mln [The Number of Working-Age Russians Will Decrease by 3.6 Million over 5 Years]. Ministry of Economic Development of the Russian Federation. URL: http://www.finmarket.ru/ themes/demography/?sec=\&id=4277703 (accessed 23 April2018).

36. Chislo bednykh v Rossii vyroslo do 23 millionov chelovek [The Number of Poor Russians Has Increased to 23 Million People]. URL: https://lenta.ru/ news/2016/06/17/poverty/ (accessed 23 April 2018).

\section{Information about the Author}

Inna V. Vasilenko, Doctor of Sciences (Philosophy), Professor, Department of Sociology, Volgograd State University, Prosp. Universitetsky, 100, 400062 Volgograd, Russian Federation, socpol@volsu.ru.

\section{Информация об авторе}

Инна Викторовна Василенко, доктор философских наук, профессор кафедры социологии, Волгоградский государственный университет, просп. Университетский, 100, 400062 г. Волгоград, Российская Федерация, socpol@volsu.ru. 